TORRES, A.C.; FAJARDO, T.V.; DUSI, A.N.; RESENDE, R.O.; BUSO, J.A. Shoot tip culture and thermotherapy in recovering virus free plants of garlic. Horticultura Brasileira, Brasília, v. 18, n. 3, p. 192-195, novembro 2.000.

\title{
Shoot tip culture and thermotherapy for recovering virus-free plants of garlic.
}

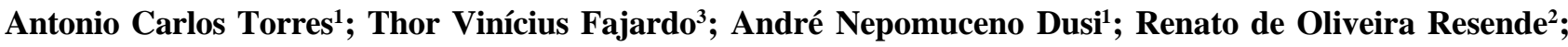 \\ José Amauri Buso ${ }^{1}$ \\ ${ }^{1 / E}$ Embrapa Hortaliças, C. Postal 218, 70.359-970, Brasília, DF; ${ }^{2}$ Universidade de Brasília, C. Postal 04.457, 70.919-970 Brasília, DF; ${ }^{3 /}$ \\ Grant from CNPq/RHAE, Embrapa Hortaliças, C. Postal 218, 70.359-970 Brasília, DF. e-mail: torres@cnph.embrapa.br
}

\begin{abstract}
Garlic shoot tip culture associated with dry heat thermotherapy (cloves exposed to $37^{\circ} \mathrm{C}$ for 35 days) were essential for recovering virus free plants of the cv Amarante. In this condition $70 \%$ of the explants developed in vitro and produced plants. A total of $77 \%$ of those plants was virus free when indexed by ISEM, which resulted in a final index of $54 \%$ of virus free plants from treated cloves. The percentage of regeneration decreased to $20 \%$ as the temperature increased up to $40^{\circ} \mathrm{C}$. However $90 \%$ of those plants were virus free, leading to a final index of $18 \%$ virus free plants out of treated cloves.
\end{abstract}

Keywords: Allium sativum L, regeneration, heat treatment.

\section{RESUMO}

Cultura de ápices caulinares e termoterapia na recuperação de plantas livres de vírus de alho.

A cultura de ápices caulinares de alho, associado à termoterapia à seco (exposição dos bulbilhos a temperatura de $37^{\circ} \mathrm{C}$, por um período de 35 dias) foi essencial para recuperação de plantas livres de vírus das cultivar de alho Amarante. Nestas condições, 70\% dos explantes inoculados se desenvolveram in vitro e produziram plantas, das quais $77 \%$ não apresentaram partículas virais quando indexadas por ISEM. Isto resulta em um índice de aproveitamento de $54 \%$ dos bulbilhos submetidos à termoterapia. O aumento da temperatura na termoterapia para $40^{\circ} \mathrm{C}$ reduziu a regeneração in vitro para $20 \%$, e $90 \%$ dessas plantas estavam livres de vírus, com um índice final de aproveitamento de $18 \%$.

Palavras-chave: Allium sativum L, regeneração, tratamento térmico.

(Aceito para publicação em 18 de setembro de 2.000)

$\mathrm{I}^{\mathrm{n}}$ general, garlic (Allium sativum L.) cultivars are agamic, not producing viable seeds, reproducing by underground cloves or vegetative topsets on the flower (Pooler \& Simon (1993). This kind of propagation usually brings diseases caused by fungi, bacteria and, mainly, viruses. Viruses tend to accumulate within host and spread to healthy plants every crop cycle, reducing yield and bulb quality.

One option to increase yield and control diseases is to use disease-free garlic cloves, obtained via shoot tip culture (Havránek, 1972, 1974; Quit, 1972; Wang \& Huang, 1974; Daniels, 1977; Conci et al., 1986; Walkey et al., 1987; Conci \& Nome 1991; Verbeek et. al., 1995). The efficiency of this process can be increased if the plants are submitted to high temperature before shoot tip excision (Murashige, 1974). One problem that may occur by using misty thermoterapy chambers is high contamination levels by fungi and bacteria, compromising the development of the explants and reducing the efficiency of the whole process.

An efficient dry heat thermotherapy protocol, associated with the shoot tip culture, which can be used to produce virus free plants of any garlic cultivar has not been described yet. The aim of this work was to develop an efficient dry heat thermotherapy method to produce virus free garlic seed. 


\section{MATERIAL AND METHODS}

Cloves of garlic, cv. Amarante were selected by size, to standardize in vitro development. They were kept in a cold chamber at $4^{\circ} \mathrm{C}$ to break dormancy. The cv Amarante was used to establish basic requirements for recovering virus free plants.

\section{Thermotherapy}

In preliminary assays, twenty nonsprouted cloves were exposed to thermotherapy at 37,40 and $45^{\circ} \mathrm{C}$ in dry chamber for 35 days, without using shoot tip culture. They were screened for the presence of these viruses by ISEM (Immunosorbent Electron Microscopy), as described below, just after sprouting. Also, standard heat thermotherapy was tested in recently sprouted cloves developed in growth chambers kept under the same temperatures as above with $80 \%$ relative humidity, for 35 days. Due to high humidity, contamination with fungi and bacteria was higher than $50 \%$, leading to the death of most sprouts. So, all the subsequent assays were conducted using dry heat thermotherapy in nonsprouted cloves.

Groups of 50 cloves of the cv. Amarante were put in trays and kept under 37,40 or $45^{\circ} \mathrm{C}$ for 35 days. As a control 50 cloves were not submitted to thermotherapy prior shoot tip culture. After thermotherapy, the cloves protection leaves were removed leaving only two pairs of rolled leaves and enclosed shoot tip tissues (10 to $20 \mathrm{~mm}$ long). Those explants were superficially disinfested with sodium hypochlorite solution for $20 \mathrm{~min}$. After disinfestation, the solution was decanted and the explants were rinsed three times with autoclaved distilled water. Next, in a laminar-air-flow hood, isolated shoot apices comprised by apical meristem and the first set of primordial leaves (Fig. 1) were transferred to nutrient tubes, one explant per tube. In the controls (not submitted to thermotherapy) the explants were excised as previously described.

Cloves of the cv. Caçador were used to further evaluate the thermotherapy method.

\section{Induction of microbulbs}

The basic culture media used to induce shoot growth consisted of mineral

Table 1. Effect of temperature exposure, for 35 days, in the recovery of virus free garlic plants, via shoot tip culture of cultivar Amarante. Brasília, Embrapa Hortaliças, 2.000.

\begin{tabular}{cccc}
\hline \multirow{2}{*}{$\mathbf{C}$ for $\mathbf{3 5}$ days } & \multicolumn{3}{c}{ Efficiency } \\
\cline { 2 - 4 } & Regeneraton $^{\mathbf{1}}(\%)$ & Virus free $^{\mathbf{2}}(\%)$ & Process $^{\mathbf{3}}(\%)$ \\
\hline 37 & $35 / 50(70)$ & $27 / 35(77)$ & $27 / 50(54)$ \\
40 & $10 / 50(20)$ & $9 / 10(90)$ & $9 / 50(18)$ \\
45 & $0 / 50(0)$ & $0 / 50(0)$ & $0 / 50(0)$ \\
\hline
\end{tabular}

${ }^{1 / N u m b e r}$ of regenerated plants/number of explants. $\chi^{2}$ significant $(\mathrm{p}<0.001)$;

${ }^{2}$ Number of virus free plants/number of regenerated plants. $\chi^{2}$ not significant $(p=0.65)$;

${ }^{3}$ Number of virus free plants/number of explants. $\chi^{2}$ significant $(\mathrm{p}<0.001)$.

salts of MS (Murashige \& Skoog, 1962), with addition of $3 \%$ sucrose, $0.2 \%$ gelrite and, in mg.. $\mathrm{L}^{-1}$ : i-inositol, 100; glicyne, 2.0; thiamin. $\mathrm{HCl}, 1.0$; piridoxin. $\mathrm{HCl}, 0.5$; nicotinic acid, 0.5 ; isopenteniladenin, 0.1 and indolbutiric acid, 0.1.

The media were dispensed into $25 \mathrm{x}$ $150 \mathrm{~mm}$ test tubes, $12.5 \mathrm{~mL}$ per tube. The tubes were capped with polypropylene closures and autoclaved $20 \mathrm{~min}$ at $121^{\circ} \mathrm{C}$ and $1.05 \times 105 \mathrm{KPa}$.

The cultures were illuminated $16 \mathrm{~h}$ per day with of $62 \mathrm{mmol} . \mathrm{m}^{-2} . \mathrm{s}^{-1}$ light intensity and exposed to $25 \pm 2^{\circ} \mathrm{C}$. After shoot development and formation of a small microbulb at the base, the plantlets were transferred to the specific media to allow microbulb development.

\section{Development of microbulbs}

Plantlets with microbulbs at the base were transferred to media composed of mineral salts of MS, with addition of $6 \%$ de sucrose e $0.2 \%$ de gelrite and, in mg.L. ${ }^{-1}$ : i-inositol, 100; glycine, 2.0; thiamine. $\mathrm{HCl}, 1.0$; piridoxine. $\mathrm{HCl}, 0.5$ and nicotinic acid, 0.5 .

After 60 days, the microbulbs with approximately 4 to $8 \mathrm{~mm}$ diameter were collected and planted, after breaking the dormancy, in pots containing a mixture of sand and vermiculite in equal parts. The microbulbs that did not sprout were kept in a cold chamber for an additional period at $5^{\circ} \mathrm{C}$ to break the dormancy.

\section{Indexing System}

The plants in pots, after 8 and 12 weeks of transplanting, were indexed by ISEM with and without particle decoration. A polyvalent policlonal antiserum (Gama \& Avila, 1988) was used for the tests which were also performed using specific policlonal antisera against the potyviruses Onion yellow dwarf virus (OYDV), Leek yellow stripe virus (LYSV), and the carlaviruses Carnation latent virus (CLV) and Shallot latent virus (SLV) (Conci \& Nome, 1991).

\section{RESULTS AND DISCUSSION}

To establish the indexing system, virus infected garlic plants were tested by ISEM, and the results with the virus specific antisera were compared to the polyvalent antiserum. The use of the polyvalent antiserum allowed the detection of all viruses identified in the virus complex so far (Dusi et al., 1994). In all further experiments, indexing was done using the polyvalent antiserum.

The cloves exposed to dry heat thermotherapy, but did not go through shoot tip culture were $100 \%$ infected with viruses. This treatment was not included in the assays to establish the best protocol to recover virus free plants. Also, plants originated from shoot tip cultures of cloves not exposed to thermotherapy (preliminary tests, data not presented) were $100 \%$ infected with viruses.

Explants excised from newly sprouted cloves, maintained in a growth chamber at $37^{\circ} \mathrm{C}$ for 35 days resulted in an in vitro regeneration of $50 \%$ only. A total of $52 \%$ of those plants were indexed as virus free (Table 1), resulting in a final efficiency of the process of $26 \%$. Explants excised from cloves exposed to $37^{\circ} \mathrm{C}$ for 35 days, under dry heat condition showed regeneration of $70 \%$ ( $\mathrm{c}^{2}$ significant, $\mathrm{p}<0.001$ ) and $77 \%$ of those plants were virus free (Table1). Cloves maintained at $40^{\circ} \mathrm{C}$ for 35 days resulted in only $20 \%$ of regeneration and $90 \%$ of the plants produced from this treatment were virus free. Raising the 
temperature did not increase the number of virus free plants produced, when regeneration occurred $\left(\mathrm{c}^{2}\right.$ not significant, $p=0.65$ ). The analysis of the results indicated that, for a 35 day period, increasing the temperature from 37 to $40^{\circ} \mathrm{C}$ reduced the morphogenetic potential of the garlic explants developing in vitro. Thermotherapy at $45^{\circ} \mathrm{C}$ in the tested period was lethal to the shoot tips.

It has been postulated that, in some cases, high temperature inactivate viruses. In other cases, virus multiplication might be inhibited or a redution in virus movement in the plant might occur (Murashige, 1974). Thus, continuous exposition of the infected plants to relatively high temperatures $\left(35\right.$ to $40^{\circ} \mathrm{C}$ ), for a period around 35 days, increases the probability of getting virus free shoot tips.

Considering the high infection level of plants originated from cloves that were heat treated but did not go through shoot tip culture, it can be concluded that tissue culture in association to thermotherapy are complementary and necessary to produce garlic virus free plants.

The shoot tip culture is the most used method to produce virus free plants. It is based in the assumption that pathogen concentration is not uniform throughout the infected plant. Cells uninvaded by pathogens are often found in the apical meristem of a rapidly elongating stem (Shabde-Moses and Murashige, 1979). In addition, in most cases, this explant maintain the genetic stability of the genotype (Grout, 1990). The use of dry heat thermotherapy at $37^{\circ} \mathrm{C}$, associated to the shoot tip culture, resulted in an procedure with a final efficiency of virus free plants of $54 \%$ of the cloves originally submitted to thermotherapy, which was statistically superior to the other tested temperatures $\left(\mathrm{c}^{2}, \mathrm{p}<0.001\right)$.

The best conditions determined above were used to produce virus free plants of the cultivar Caçador, resulting in a final efficiency of $64 \%$. No statistical differences were detected for regeneration and final efficiencies by the $\mathrm{c}^{2}$ test when using the two distict cultivars ( $p=0.36$ and $p=0.42$, respectively).

The efficiency of recovering virus free plants with dry heat treatment at $37^{\circ} \mathrm{C}$ associated to shoot tip culture was significantly superior to all other tested protocols. This procedure is now being

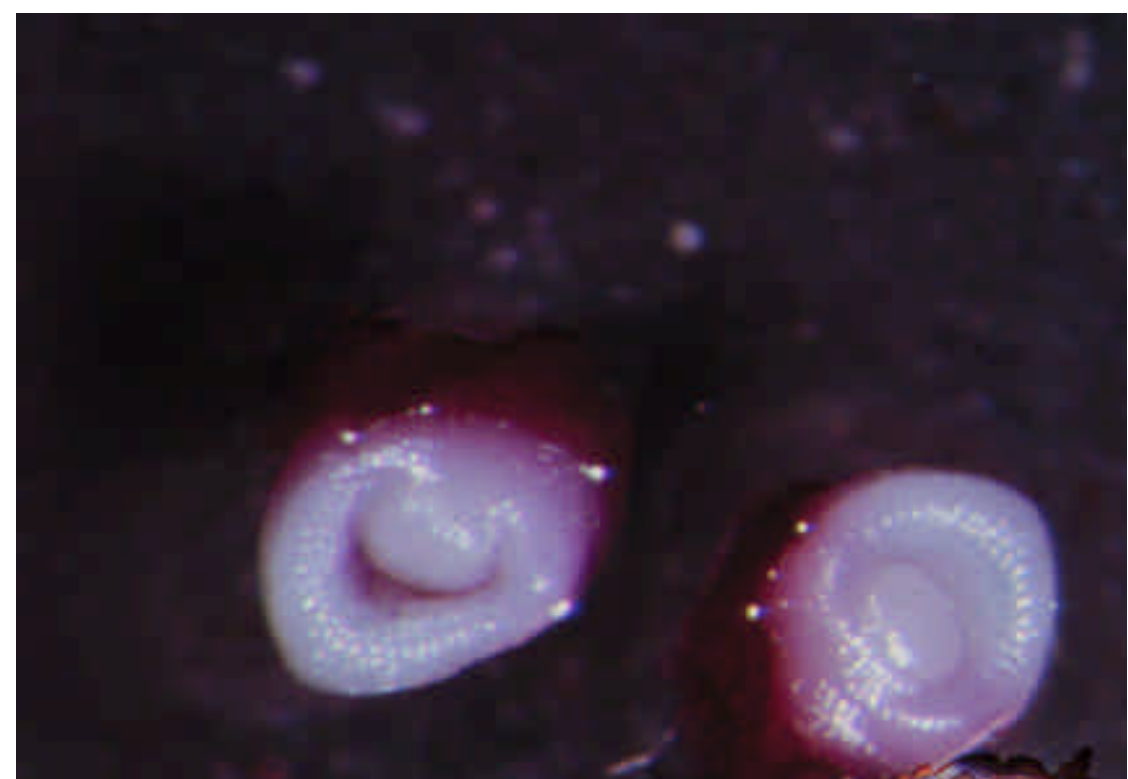

Figure 1. Shoot tips of garlic, consisting of apical meristem and a set of leaf primordium, used to establish in vitro cultures. Brasília, Embrapa Hortaliças, 2.000.

Table 2. Effect of dry heat thermotherapy $\left(37^{\circ} \mathrm{C}\right.$ for 40 days) in the production of virus free garlic plants of the cultivars Amarante and Caçador. Brasília, Embrapa Hortaliças, 2.000.

\begin{tabular}{lcc}
\hline \multirow{2}{*}{ Cultivar } & \multicolumn{2}{c}{ Efficiency } \\
\cline { 2 - 3 } & Regeneration1 (\%) & Process2 (\%) \\
\hline Amarante & $35 / 50(70)$ & $27 / 50(54)$ \\
Caçador & $40 / 50(80)$ & $32 / 50(64)$ \\
\hline
\end{tabular}

${ }^{1 /} \chi^{2}$ not significant $(\mathrm{p}=0.36)$;

${ }^{2} \chi^{2}$ não significant $(\mathrm{p}=0.42)$.

applied to other garlic cultivars and the expected consequence is the possibility of virus free garlic cloves production in large scale.

\section{LITERATURE CITED}

CONCI, V.C.; NOME, S.F. Virus free garlic (Allium sativum L.) plants obtained by thermotherapy and meristem tip culture. Journal of Phytopathology, v. 132, p. 186-192, 1991.

CONCI, V.C.; MORICONI, D.N.; NOME, S.F. Cultivo de meristemas apicales de seis tipos clonales de ajo (Allium sativum L.). Phyton. v. 46, n. 2, p. 187-194, 1986.

DANIELS, J. Regeneração de clones de alho (Allium sativum L.) infectados por um Potyvirus. Brasília, UnB, 1977. 56 p. (Tese mestrado).

DUSI, A.N.; FAJARDO, T.V.M.; CUPERTINO, F.P. Serological identification of garlic (Allium sativum L.) viroses in Brazil. Fitopatologia Brasileira, Brasília, v. 19, p. 298, 1999. Resumo do XXVII Congresso Brasileiro de Fitopatologia, Itajai, SC. 1999

GAMA, M.I.C.S.; AVILA, A.C. Detecção de vírus em alho por latex sensibilizado e microscopia eletrônica imuno-específica. Fitopatologia Brasileira, Brasília, v. 3, n. 1, p. 66-69, 1988.
HAVRÁNEK, P. Viruprosté klony Cesneku Kuchynské'ho Zishané meristematických Katur. Ochrana Rostlin, v. 8, p. 291-298, 1972.

HAVRANEK, P. Effect of virus disease on garlic yield. Ochrana Rostlin, v. 10, p. 251-256, 1974.

MURASHIGE, T. Plant cell and organ culture methods in the establishment of pathogen-free stock. In: Dimock A.W. Lectures. New York: Cornel University, 1974. 26 p.

MURASHIGE, T.; SKOOG, F. A revised medium for rapid growth and bioassays with tobacco tissue cultures. Physiologia Plantarum, v. 15, p. 473-497, 1962.

POOLER, M.R.; SIMON, P.W. Garlic flowering in response to clone, photoperiod, growth temperature, and cold storage. HortScience, v. 28, p. 1085-1086, 1993.

QUIOT, J.B.; MESSIAEN, C.M.; MARROU, J.; LEROUX, J.P. Régénération par culture de méristèmes de clones d'ail infectés de façon chronique par le virus de la mosaique de l'ail. Actas III Congresso da União Fitopatológica Mediterranea, Oeiras, Portugal, 22-28 outubro, p. 429-433, 1972.

SHABDE-MOSES, M; MURASHIGE, T. Nicotiana:procedures for experimental use. Organ culture, USDA Technical bulletin 1586, p. $40-51,1979$. 
VERBEEK, M.; DIJK, P.V.; WELL, P.M.A. Efficiency of eradication of four viruses from garlic (Allium sativum L.) by meristem-tip culture. European Journal of Plant Pathology, v. 101, p. 231-139, 1995.
WALKEY, D.G.A.; WEBB, M.J.; BOLLAND, C.J.; MILLER, A. Production of virus free garlic (Allium sativum L.) and shallot (Allium ascolonicum L.) by meristem tip culture. The Journal of Horticultural Science, v. 82, n. 2, p. 211-20, 1987.
WANG, P.; HUANG, L. Studies on the shoot meristem culture of (Allium sativum L.). Journal of the Chinese Society of Horticultural Science, v. 20, p. 79-87, 1974. 